THE END OF JAPANESE CINEMA 
STUDIES OF THE WEATHERHEAD EAST ASIAN INSTITUTE,

COLUmbia University. The Studies of the Weatherhead East Asian Institute of Columbia University were inaugurated in 1962 to bring to a wider public

the results of significant new research on modern and contemporary East Asia. 


\section{THE END OF JAPANESE CINEMA}

Industrial Genres, National Times, and Media Ecologies 
(C) 2017 DUKE UNIVERSITY PRESS All rights reserved

Printed in the United States of America on acid-free paper $\infty$ Text designed by Courtney Leigh Baker

Typeset in Arno Pro and Din by Westchester Publishing Services

Library of Congress Cataloging-in-Publication Data

Names: Zahlten, Alexander, [date] author.

Title: The end of Japanese cinema : industrial genres, national times, and media ecologies / Alexander Zahlten.

Description: Durham : Duke University Press, 2017. | Series: Studies of the Weatherhead East Asian Institute, Columbia University | Includes bibliographical references and index. | Description based on print version record and cIP data provided by publisher; resource not viewed.

Identifiers:

LCCN 2017012588 (print)

LCCN 2017015688 (ebook)

ISBN 9780822372462 (ebook)

ISBN 9780822369295 (hardcover : alk. paper)

ISBN 9780822369448 (pbk. : alk. paper)

Subjects: LCSH: Motion pictures_Japan-History—2oth century. | Mass media_JapanHistory-2oth century.

Classification: LCC PN1993.5.J3 (ebook) | LCC PN1993.5.J3 Z34 2017 (print) | DDC $791.430952-\mathrm{dc} 23$

LC record available at https://lccn.loc.gov/2017012588

COVER ART: Design and illustration by Matthew Tauch. 